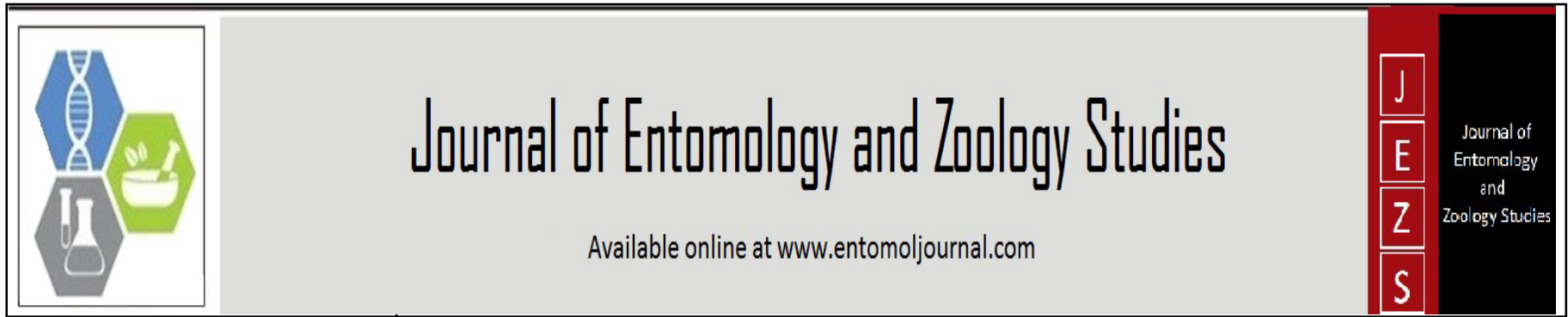

E-ISSN: 2320-7078

P-ISSN: 2349-6800

www.entomoljournal.com

JEZS 2021; 9(5): 425-429

(C) $2021 \mathrm{JEZS}$

Received: 12-06-2021

Accepted: 03-08-2021

Kota Tejeswari

Department of Entomology,

Naini Institute of Agricultural

Sciences, Sam Higginbottom

University of Agriculture,

Technology and Sciences,

Prayagraj, Uttar Pradesh, India

Ashwani Kumar

Department of Entomology,

Naini Institute of Agricultural

Sciences, Sam Higginbottom

University of Agriculture,

Technology and Sciences,

Prayagraj, Uttar Pradesh, India

Corresponding Author:

Kota Tejeswari

Department of Entomology,

Naini Institute of Agricultural

Sciences, Sam Higginbottom

University of Agriculture,

Technology and Sciences,

Prayagraj, Uttar Pradesh, India

\section{Comparative efficacy of chemicals with biopesticides against tomato fruit borer, Helicoverpa armigera (Hubner) on Tomato, Solanum lycopersicum (L.) under field conditions}

\author{
Kota Tejeswari and Ashwani Kumar
}

DOI: https://doi.org/10.22271/j.ento.2021.v9.i5f.8860

\section{Abstract}

The present investigation entitled Comparative efficacy of chemicals with biopesticides against Tomato fruit borer, Helicoverpa armigera (hubner) on Tomato, Solanum lycopersicum (L.) under field conditions. cultivar i.e. Pusa Ruby was conducted during December to March 2019-20 at Central Research Farm, SHUATS, Naini, Prayagraj. The incidence of Helicoverpa armigera in tomato was starting from early stage of flowering till to the harvesting. The approaches for chemical management of tomato fruit borer were found effective than control. Two applications of seven insecticides viz; Neem oil @ 5\%, Spinosad 45 SC @ 0.4\%, Bacillus thuringiensis@5\%, Neem seed kernel extract @ 5\%, Flubendiamide 39.35 SC @ 0.2\%, Chlorantraniliprole 18.5 SC @ 0.4\%, and Nisco sixer plus @ 1\% were evaluated against Tomato fruit borer, Helicoverpa armigera. Minimum percent of larval reduction and $\mathrm{B}: \mathrm{C}$ ratio were observed in Spinosad (80.6 and 1:7.0) followed by Chlorantraniliprole (73.7 and 1:6.8) < Flubendamide (65.5 and 1:6.4) < Nisco sixer plus (63.3 and 1:5.9) < Neem oil $(62.6$ and 1:5.6) < Neem seed kernel extract (61.2 and 1:5.6).

Keywords: Benefit cost ratio, Helicoverpa armigera, larval reduction, insecticides, tomato fruit borer

\section{Introduction}

Tomato, Solanum lycopersicum (L.) is one of the most important commercial vegetable crop grown all over the world and occupies the third position among vegetables in area and production in the world (Bhavana and Nagar, 2019) ${ }^{[2]}$. It belongs to the family Solanaceae and said to be the native of tropical America. The major tomato producing states of India are Maharashtra, Bihar, Karnataka, Uttar Pradesh, Himachal Pradesh, Orissa, Andhra Pradesh, Madhya Pradesh and Assam. The fruits are eaten raw or cooked. Large quantities of tomatoes are used to prepare soup, juice, ketchup, pickle, paste and powder (Choudary, 2002) [3]. Tomato is grown throughout world either outdoors or indoors, mainly in China, India, U.S.A., Italy, Turkey, Mexico and Japan etc. The important insect pest of tomato is fruit borer, Helicoverpa armigera (Hubner); whitefly, Bemisia tabaci (Gen.); jassids, Amrasca devastans (Ishida); leaf miner, Liriomyza trifolii (Blanchard); potato aphid, Myzus persicae (Thomas) and hadda beetle, Epilachna dodecastigma (Widemann). But in India fruit borer is one of the most important pests of tomato, limiting production and market value of crop produce. The fruit borer, Helicoverpa armigera (Hubner) is the most destructive pest of tomato in India, which is commonly known as gram pod borer, American bollworm and fruit borer (Meena and Raju, 2014.) ${ }^{[11]}$. It is known to cause serious damage to hundreds of economically important crops all over the world. In India it is reported to be feeding on 182 plant species across 47 families (Manjunath et al., 1985) ${ }^{[10]}$. Helicoverpa armigera is a destructive polyphagous pest occurring on tomato, and many others crops, inflicting substantial loss every year. To control this insect pest and to save the crop, pesticides are being used in large quantities by human being. But the continuous and enormous use of same or similar groups of pesticides causes problem of pesticide residues in foodstuff and other environmental contamination. This has promoted the necessity for the development of new, safer, biodegradable insecticides and known insecticidal alternatives that could be feasible and effective for insect pest management. Spinosad is one of such new chemicals which are derived from fermentation broth of soil actinomycetes, Saccharopolyspora spinosa, containing a naturally occurring mixture of Spinosyn A and Spinosyn D. 
Spinosad have rapid contact and ingestion activity in insects, causing excitation of the nervous system, leading to cessation of feeding and paralysis (Faqiri and Kumar, 2016) ${ }^{[5]}$.

\section{Materials and Methods}

The present investigation was conducted during the Rabi season 2019-2020 at SHUATS, at the Central research field, SHUATS (Sam Higginbottom University of Agriculture, Technology and Sciences), Prayagraj, Uttar Pradesh, (India) at a latitudinal-longitudinal extent of $25^{\circ} 27^{\prime} \mathrm{N}, 81^{\circ} 44^{\prime} \mathrm{E}$. City rises to a height of about 98 meters from the sea level and is positioned at the meeting point of River Ganga and River Yamuna. The material used and methods used to carry out these investigations are described below:

The trails were laid out in RBD having eight treatments and three replications with the plot size $2 \times 2 \mathrm{~m}$. The experiments were carried out in the tomato variety Pusa rubi. One round of spray was given at fifteen days interval using a hand operated sprayer during morning hours to avoid photo oxidation of chemicals. T1 Neem oil @ 5 ml, T2 Spinosad 45 SC @ 0.4\%, T3 Bacillus thuringiensis @ 5\%, T4 Neem seed kernel extract @ 5\%, T5 Flubendiamide 39.5 SC @ 0.2ml, T6 Chlorantraniliprole 18.5 SC @ 0.4ml T7 Nisco sixer plus @ $1 \mathrm{ml}$ and T8 Control. Observations on percent population reduction were made in tomato fruit borer on 5 randomly selected plants in each replication along with the unsprayed control. Pre and post treatments observations were recorded on 3rd, 7th and 14th days of each spray. The percent population reduction of tomato fruit borer damage over control in field conditions was calculated. The data averaged into respective parameter requisite were subjected to suitable transformation. After analysis, data was accommodated in the table as per the needs of objectives for interpretation of results. The standard procedures in agriculture statistics given by Gomez and Gomez (1984) were consulted throughout. The interpretation of data was done by using the critical difference value calculated at 0.05 probability level. The level of significance will be expressed at 0.05 probabilities.

\section{Results and Discussion}

The results of studies undertaken during Rabi, 2019-20 on "Comparative efficacy of chemicals with biopesticides against tomato fruit borer, Helicoverpa armigera (hubner) on tomato, Solanum lycopersicum (L.) Under field conditions” are presented in the following heads.

Assessment of infestation: Number basis
First spray: percent larval reduction

The efficacy of certain chemical insecticide and bio pesticides against Tomato fruit borer are depicted in the Table 1.

\section{Percent larval reduction of fruit borer 3 DAS}

The data on the percent larval reduction of fruit borer on the three days after first spray revealed that all the treatments were significantly superior over control. Among all the treatments maximum reduction of fruit borer was observed with Spinosad (68.9) followed by Chlorantraniliprole (66.8), Flubendamide (57.1), Nisco sixer plus (56.3), Neem oil (55.3), Neem seed kernel extract (52.3) and Bacillus thuringiensis (40.7) is found to be least effective than all treatments.

\section{Percent larval reduction of fruit borer 7 DAS}

The data on the percent larval reduction of fruit borer on the seven days after first spray revealed that all the treatments were significantly superior over control. Among all the treatments maximum reduction of fruit borer was observed with Spinosad (82.7) followed by Chlorantraniliprole (80.6), Flubendamide (74.1), Nisco sixer plus (72.4), Neem oil (71.5), Neem seed kernel extract (68.7) and Bacillus thuringiensis (51.3) is found to be least effective than all treatments.

\section{Percent larval reduction of fruit borer 14 DAS}

The data on the percent larval reduction of fruit borer on the fourteen days after first spray revealed that all the treatments were significantly superior over control. Among all the treatments maximum reduction of fruit borer was observed with Spinosad (80.4) followed by Chlorantraniliprole (69.7), Flubendamide (65.7), Nisco sixer plus (62.3), Neem oil (61.5), Neem seed kernel extract (56.4) and Bacillus thuringiensis (53.9) is found to be least effective than all treatments.

\section{Mean $\left(3^{\text {rd }}, 7^{\text {th }}\right.$ and $14^{\text {th }}$ DAS) Percent larval reduction of fruit borer after first spray}

The data on the mean $\left(3^{\text {rd }}, 7^{\text {th }}\right.$ and $14^{\text {th }}$ DAS) percent larval reduction of fruit borer after first spray revealed that all the treatments were significantly superior over control. Among all the treatments maximum reduction of fruit borer was observed with Spinosad (77.8) followed by Chlorantraniliprole (72.4), Flubendamide (65.7), Nisco sixer plus (63.6), Neem oil (62.7), Neem seed kernel extract (61.4) and Bacillus thuringiensis (48.6) is found to be least effective than all treatments.

Table 1: Comparative efficacy of selected chemicals and biopesticides against tomato fruit borer, H. armigera on different days after 1st spray during Rabi season 2019-2020.

\begin{tabular}{|c|c|c|c|c|c|c|}
\hline \multirow{2}{*}{\multicolumn{2}{|c|}{ Treatments }} & \multicolumn{5}{|c|}{ Percent larval reduction } \\
\hline & & Before Spraying & 3 DAS & 7 DAS & 14 DAS & Mean \\
\hline T1 & Neem oil & 5.4 & $55.3(48.0)$ & 71.5(57.7) & $61.5(51.7)$ & $62.8(52.4)$ \\
\hline $\mathrm{T} 2$ & Spinosad & 5.0 & $68.9(56.1)$ & $82.7(65.4)$ & $80.4(63.7)$ & $77.3(61.7)$ \\
\hline $\mathrm{T} 3$ & Bacillus thuringiensis & 5.06 & $40.7(39.5)$ & $51.3(45.7)$ & $53.9(47.2)$ & $48.6(44.2)$ \\
\hline T4 & Neem Seed Kernel Extract (NSKE) & 5.6 & $52.3(46.3)$ & $68.7(56.0)$ & $63.2(52.6)$ & $61.4(51.6)$ \\
\hline $\mathrm{T} 5$ & Flubendiamide & 4.6 & $57.1(49.1)$ & 74.1(59.6) & $65.7(54.1)$ & $65.6(54.2)$ \\
\hline T6 & Chlorantraniliprole & 4.8 & $66.8(54.8)$ & $80.6(63.9)$ & $69.7(56.6)$ & 72.4(58.4) \\
\hline T7 & Nisco Sixer Plus & 4.4 & $56.2(48.5)$ & $72.4(58.3)$ & $62.3(52.1)$ & $63.6(53.0)$ \\
\hline T8 & Control/water spray & 5.8 & $0(0.00)$ & $0(0.00)$ & $0(0.00)$ & $0(0.00)$ \\
\hline & F- test & NS & $\mathrm{S}$ & $\mathrm{S}$ & $\mathrm{S}$ & $\mathrm{S}$ \\
\hline & S. Ed $( \pm)$ & 0.539 & 4.678 & 3.067 & 3.218 & 2.955 \\
\hline & C. D. $(P=0.05)$ & NS & 10.131 & 6.643 & 6.670 & 6.339 \\
\hline
\end{tabular}

Figures in parenthesis are arc sin transformed value 
Second spray: percent larval reduction

The efficacy of certain chemical insecticide and bio pesticides against Tomato fruit borer are depicted in the Table 2. The data on percent larval reduction of fruit borer before spraying revealed that the results were statistically non-significant.

\section{Percent larval reduction of fruit borer 3 DAS}

The data on the percent larval reduction of fruit borer on the three days after second spray revealed that all the treatments were significantly superior over control. Among all the treatments maximum reduction of fruit borer was observed with Spinosad (80.4) followed by Chlorantraniliprole (64.2), Flubendamide (58.1), Nisco sixer plus (52.8), Neem oil (52.5), Neem seed kernel extract (51.2) and Bacillus thuringiensis (45.5) is found to be least effective than all treatments.

\section{Percent larval reduction of fruit borer 7 DAS}

The data on the percent larval reduction of fruit borer on the seven days after second spray revealed that all the treatments were significantly superior over control. Among all the treatments maximum reduction of fruit borer was observed with Spinosad (87.3) followed by Chlorantraniliprole (79.2), Flubendamide (68.5), Nisco sixer plus (68.0), Neem oil (67.7), Neem seed kernel extract (65.4) and Bacillus thuringiensis (55.6) is found to be least effective than all treatments.

\section{Percent larval reduction of fruit borer 14 DAS}

The data on the percent larval reduction of fruit borer on the fourteen days after second spray revealed that all the treatments were significantly superior over control. Among all the treatments maximum reduction of fruit borer was observed with Spinosad (84.3) followed by Chlorantraniliprole (81.9), Flubendamide (69.5), Nisco sixer plus (68.2), Neem oil (67.3), Neem seed kernel extract (66.9) and Bacillus thuringiensis (58.5) is found to be least effective than all treatments.

\section{Mean $\left(3^{\text {rd }}, 7^{\text {th }}\right.$ and $14^{\text {th }}$ DAS) Percent larval reduction of fruit borer after second spray}

The data on the mean ( $3^{\text {rd }}, 7^{\text {th }}$ and $14^{\text {th }}$ DAS) percent larval reduction of fruit borer after second spray revealed that all the treatments were significantly superior over control. Among all the treatments maximum reduction of fruit borer was observed with Spinosad (84.0) followed by Chlorantraniliprole (75.1), Flubendamide (65.4), Nisco sixer plus (63.0), Neem oil (62.5), Neem seed kernel extract (61.1) and Bacillus thuringiensis (53.2) is found to be least effective than all treatments.

Table 2: Comparative efficacy of selected chemicals and bio-pesticides against tomato fruit borer, H. armigera on different days after 2nd spray during Rabi season 2019-2020.

\begin{tabular}{|c|c|c|c|c|c|c|}
\hline \multirow{2}{*}{\multicolumn{2}{|c|}{ Treatments }} & \multicolumn{5}{|c|}{ Percent larval reduction } \\
\hline & & Before Spraying & 3 DAS & 7 DAS & 14 DAS & Mean \\
\hline T1 & Neem oil & 3.4 & $52.5(46.4)$ & $67.7(55.4)$ & $67.3(55.1)$ & $62.5(52.3)$ \\
\hline $\mathrm{T} 2$ & Spinosad & 1.8 & $80.4(63.8)$ & $87.3(69.2)$ & $84.3(66.7)$ & $84.0(66.5)$ \\
\hline T3 & Bacillus thuringiensis & 4.0 & $45.5(42.3)$ & $55.6(48.2)$ & 58.5 (49.9) & $53.2(46.8)$ \\
\hline $\mathrm{T} 4$ & Neem Seed Kernel Extract (NSKE) & 3.2 & $51.2(45.6)$ & $65.4(53.9)$ & $66.9(54.9)$ & $61.1(51.5)$ \\
\hline $\mathrm{T} 5$ & Flubendiamide & 2.7 & $58.1(49.7)$ & $68.5(55.9)$ & $69.5(56.5)$ & $65.4(54.0)$ \\
\hline T6 & Chlorantraniliprole & 2.6 & $64.2(53.3)$ & $79.2(62.9)$ & $81.9(64.8)$ & $75.1(60.3)$ \\
\hline $\mathrm{T} 7$ & Nisco Sixer Plus & 3.3 & $52.8(46.6)$ & $68.0(55.5)$ & $68.2(55.7)$ & $63.0(52.6)$ \\
\hline T8 & Control/water spray & 4.7 & $0(0.00)$ & $0(0.00)$ & $0(0.00)$ & $0(0.00)$ \\
\hline & F- test & NS & $\mathrm{S}$ & $\mathrm{S}$ & $\mathrm{S}$ & $\mathrm{S}$ \\
\hline & S. Ed $( \pm)$ & 0.852 & 4.068 & 3.320 & 2.973 & 2.818 \\
\hline & C. D. $(P=0.05)$ & NS & 8.809 & 7.190 & 6.437 & 6.130 \\
\hline
\end{tabular}

Figures in parenthesis are arc sin transformed value

Mean ( $1^{\text {st }}$ and $2^{\text {nd }}$ sprays) percent larval reduction.

It is evident from the table 3 that the data on the mean $\left(1^{\text {st }}\right.$ and $2^{\text {nd }}$ sprays) percent larval reduction of fruit borer from all the treatments were significantly superior over control. Among all the treatments maximum reduction of fruit borer was observed with Spinosad (80.6) followed by Chlorantraniliprole (73.7), Flubendamide (65.5), Nisco sixer plus (63.3), Neem oil (62.6), Neem seed kernel extract (61.2) and Bacillus thuringiensis (50.9) is found to be least effective than all treatments.

Table 3: Comparative efficacy of certain bio-pesticides against tomato fruit borer, H. armigera during Rabi season (Mean of $1^{\text {st }}$ and $2^{\text {nd }}$ spray) 2019-20.

\begin{tabular}{|c|c|c|c|c|}
\hline \multicolumn{2}{|c|}{ Treatments } & \multicolumn{3}{c|}{ Percent larval reduction } \\
\cline { 2 - 4 } & & First spray & Second spray & Mean \\
\hline T1 & Neem oil & $62.8(52.4)$ & $62.5(52.3)$ & $62.6(52.3)$ \\
\hline T2 & Spinosad & $77.3(61.7)$ & $84.0(66.5)$ & $80.6(63.9)$ \\
\hline T3 & Bacillus thuringiensis & $48.6(44.2)$ & $53.2(46.8)$ & $50.9(45.5)$ \\
\hline T4 & Neem Seed Kernel Extract (NSKE) & $61.4(51.6)$ & $61.1(51.5)$ & $61.2(51.5)$ \\
\hline T5 & Flubendiamide & $65.6(54.2)$ & $65.4(54.0)$ & $65.5(54.0)$ \\
\hline T6 & Chlorantraniliprole & $72.4(58.4)$ & $75.1(60.3)$ & $73.7(59.1)$ \\
\hline T7 & Nisco Sixer Plus & $63.6(53.0)$ & $63.0(52.6)$ & $63.3(52.7)$ \\
\hline T8 & Control/water spray & $0(0.00)$ & $0(0.00)$ & $0(0.00)$ \\
\hline & F- test & S & S & S \\
\hline \multicolumn{2}{r|}{} \\
\hline
\end{tabular}


All the treatments were found to be significantly superior to control in reducing percent larval reduction. The highest larval reduction was noticed in Spinosad 45 SC treated plots followed by Chlorantraniliprole 18.5 SC, Flubendiamide 39.35 EC, Nisco sixer plus, Neem oil, Neem seed kernel extract and Bacillus thringiensis was least effective among all selected treatments.

The maximum larval reduction was recorded in Spinosad 45 SC. The results were supported by Game et al. (2018) ${ }^{[6]}$ and Shinde et al. (2011) [19], Goshal et al. (2013), Meena and Raju (2013) ${ }^{[11]}$ and Baber et al. (2016). Chlorantraniliprole 18.5 SC was found to be next best effective. The results was supported by Abbas et al. (2015) ${ }^{[1]}$, Rani et al. (2018) ${ }^{[15]}$ and Patel et al. (2016) ${ }^{[13]}$. Flubendiamide 39.35 EC was found to be next effective treatment and its results was supported by Sridhar et al. (2014) [21], Verma et al. (2015) [23] and Thiruveni and Karthik (2017) ${ }^{[22]}$. Nisco sixer plus was found to be next effective. It is organic in nature and control lepidopteran caterpillars. Botanicals like Neem oil and Neem seed kernel extract was less effective when compared to chemical insecticides. But lower toxicity to the environment as well as human being neem seed extract is the most promising insecticide for the effective management of tomato fruit worm larvae. Shah et al. (2013) ${ }^{[18]}$, Rahman et al. (2014)
${ }^{[14]}$, Mustafiz et al. (2015) ${ }^{[12]}$ and Dialoke (2017) ${ }^{[4]}$. Bacillus thringiensis was least effective against tomato fruit borer supported by Kumar et al. (2017) ${ }^{[9]}$. The present investigation supports the observation of Kumar and Sarada (2015) ${ }^{[8]}$ and Sreedhar (2019) ${ }^{[20]}$ most effective treatment tomato fruit borer was Spinosad, Chlorantraniliprole and Flubendiamide.

\section{Economics of treatment}

The yield among the treatments were significant (Table 4). The highest yield was recorded in Spinosad 45 SC (230q/ha), followed by Chlorantraniliprole 18.5 SC (220q/ha), Flubendiamide 39.35 SC (196q/ha), Nisco sixer plus (171q/ha), Neem oil (160q/ha), Neem kernel seed extract (157q/ha), Bacillus thuringiensis (151q/ha) as compared to control T8 (113q/ha). When cost benefit ratio was worked out, interesting results was achieved. Among the treatment studied, the best and most economical treatment was Spinosad 45 SC (1:7.0), followed by Chlorantraniliprole 18.5 SC (1:6.8), Flubendiamide 39.35 SC (1:6.4) Nisco sixer plus (1:5.9), Neem oil (1:5.6), Neem seed kernel extract (1:5.6), Bacillus thuringiensis $(1: 5.2)$ as compared to control T8 (1:4.2).

Table 3: Economics of treatment

\begin{tabular}{|c|c|c|c|c|c|c|c|}
\hline Treatments & $\begin{array}{c}\text { Yield of } \\
\text { q/ha }\end{array}$ & \begin{tabular}{|c} 
Cost of yield / \\
Rs/q \\
\end{tabular} & \begin{tabular}{|c|}
$\begin{array}{c}\text { Total Cost yield } \\
\text { (Rs.) }\end{array}$ \\
\end{tabular} & $\begin{array}{l}\text { Common } \\
\text { cost (Rs.) }\end{array}$ & $\begin{array}{l}\text { Treatment } \\
\text { Cost (Rs.) }\end{array}$ & $\begin{array}{c}\text { Total cost } \\
\text { (Rs.) }\end{array}$ & $\mathrm{C}: \mathrm{B}$ ratio \\
\hline Neem oil & 160 & 2500 & $4,00,000$ & 67050 & 3238 & 70,288 & 1:5.6 \\
\hline Spinosad & 230 & 2500 & $5,75,000$ & 67050 & 14984 & 82,034 & $1: 7.0$ \\
\hline Bacillus thuringiensis & 151 & 2500 & $3,77,500$ & 67050 & 4300 & 71,350 & $1: 5.2$ \\
\hline Neem Seed Kernel Extract (NSKE) & 157 & 2500 & $3,92,200$ & 67050 & 2420 & 69,470 & $1: 5.6$ \\
\hline Flubendiamide & 196 & 2500 & $4,90,600$ & 67050 & 9060 & 76,110 & 1:6.4 \\
\hline Chlorantraniliprole & 220 & 2500 & $5,50,000$ & 67050 & 13392 & 80,442 & 1:6.8 \\
\hline Nisco Sixer Plus & 171 & 2500 & $4,27,500$ & 67050 & 4810 & 71,860 & $1: 5.9$ \\
\hline Control/water spray & 113 & 2500 & $2,82,500$ & 67050 & - & 67,050 & $1: 4.2$ \\
\hline
\end{tabular}

Higher yield (230q/ha) and higher cost benefit ratio of (1:7) was obtained from spinosad treated plots and lowest (1:5.6) in control plot and proved to be best among treatments. The highest cost benefit ratio was obtained in treatment of Spinosad 45 SC @0.4ml/lit the result were supported by Kalita et al., (2016) ${ }^{[7]}$, Sekhara et al. (2016) and Game et al. (2018) ${ }^{[6]}$. The next highest cost benefit ratio was obtained in the treatment of chlorantraniliprole @ 0.005\% the results were supported by Safna et al. (2018) ${ }^{[17]}$ and Patel et al. (2018). The third highest cost benefit ratio was recorded in Flubendiamide 39.35 EC @ 0.2ml/lit the results was supported by Regmi et al. (2018) ${ }^{[16]}$. The fourth highest cost benefit ratio was recorded in neem oil @ $5 \mathrm{ml}$ followed by Neem seed kernel extract @ 5\% the results was supported by Faqiri and Kumar (2016) ${ }^{[5]}$. The lowest yield can be identified in Bacillus thuringiensis @ 25g/ha which corroborates the present findings. The minimum cost benefit ratio was obtained in Bacillus thuringiensis (1:5.6) due to its less effectiveness compared to chemical insecticides with low efficacy against pest the results was supported by Kumar et al. $(2017)^{[9]}$.

\section{Conclusion}

From the critical analysis of the present findings it was observed that incidence of Helicoverpa armigera in tomato was starting from early stage of flowering till to the harvesting. The approaches for chemical management of tomato fruit borer were found effective than control. So, it can be concluded that among all the treatments, minimum percent of larval reduction and B:C ratio were observed in Spinosad (80.6 and 1:7.0) followed by Chlorantraniliprole (73.7 and 1:6.8), Flubendamide (65.5 and 1:6.4), Nisco sixer plus (63.3 and 1:5.9), Neem oil (62.6 and 1:5.6), Neem seed kernel extract (61.2 and 1:5.6), Bacillus thuringiensis (50.9 and 1:5.2), untreated control (water spray) (63.3 and 1:4.2) respectively. Hence, this finding can be useful for the farmers in feasible manner for sustainable production of tomato.

\section{Acknowledgements}

The authors acknowledge the Head, Department of Entomology - Naini Institute of Agricultural Sciences, Sam Higginbottom University of Agriculture, Technology and Sciences, Prayagraj, Uttar Pradesh, India for proving the facilities for the experiment, my guides and co-guides for their support and guidelines in conducting the experiment.

\section{References}

1. Abbas G., Hassan, N, Farhan, M, Haq I, Karar H. Effect of Selected Insecticides on Helicoverpa armigera Hubner (Lepidoptera: Noctuidae) on Tomato (Lycopersicon esculentum Miller) and Their Successful Management. Journal of Advances in Entomology 2015;3:16-23.

2. Bhavana P, Nagar S. Comparative bio efficacy of weed extracts against tomato fruit borer (Helicoverpa 
armigera) on tomato (Lycopersicon esculentum). Journal of Entomology and Zoology Studies 2019;7(6):252-258.

3. Choudary BR. Important of tomato vegetable crop. P. B 2002;121(4):292-296.

4. Dialoke SA. Effect of neem seed oil on Helicoverpa armigera on pigeonpea in Nigeria. Indian Journal of Entomology 2017;79(2):125-129.

5. Faqiri M, Kumar A. Management of tomato fruit borer (Helicoverpa armigera (Hubner) by chemical insecticides and neem products. International Journal of Multidisciplinary Research and Development 2016;3(6):82-85.

6. Game L, Nagar S, Simon S. Comparative efficacy of selected chemical insecticides and neem products against tomato fruit borer [Helicoverpa armigera (Hubner)] in Allahabad. Journal of Pharmacognosy and Phytochemistry 2018;7(4):2215-2218.

7. Kalita H, Avasthe RK, Gopi R, Kumar A, Rai D. Assessment of Damage and Yield Losses of Tomato Fruit Borer and its Biorational Management. Indian Journal of Hill Farming 2016;30(1):19-22.

8. Kumar GVS, Sarada O. Field efficacy and economics of some new insecticide molecules against lepidopteran caterpillars in chickpea. Journal of Current Biotica 2015;9(2):153-158.

9. Kumar RK, Rao CS, Bushan VS, Reddy KN. BioEfficacy of Different Insecticides against Fruit Borer (Helicoverpa armigera) in Tomato (Lycopersicon esculentum Mill.). International journal of pure and applied bioscience 2017;5(4):846-852.

10. Manjunath TM, Bhatnagar VS, Pawar CS, Sithanantham S. Economic importance of Heliothis spp. In India and an assessment of their natural enemies and hosts. Proc. Of Workshop on Biocontrol of Heliothis, ICRISAT patancheru, A.P 1985, 1-50.

11. Meena LK, Raju SVS. Bioefficacy of newer insecticides against tomato fruit borer, Helicoverpa armigera (Hubner) on tomato, Lycopersicon esculentum Mill under field conditions. An international quarterly journal of life sciences 2014;9(1):347-350.

12. Mustafiz SSB, Chowdhury MTI, Akter A. Efficacy of Some Botanicals in Controlling Fruit Borer (Heliothis armigera) in Tomato. Academic Journal of Entomology 2015;8(3):140-149.

13. Patel RD, Parmar VR, Patel NB. Bio-efficacy of Chlorantraniliprole 35 WG against Helicoverpa armigera (Hubner) Hardwick in Tomato. Journal of Trends in Biosciences 2016;9(15):793-798.

14. Rahman AKMZ, Haque MH, Alam SN, Mahmudunnabi M, Dutta NK. Efficacy of Botanicals against Helicoverpa armigera (Hubner) in Tomato. Journal of Agriculturists 2014;12(1):131-139.

15. Rani DS, Kumar SP, Venkatesh MN, Sri CHNS, Kumar KA. Bio efficacy of insecticides against gram pod borer, Helicoverpa armigera in Redgram. Journal of Entomology and Zoology Studies 2018;6(2):3173-3176.

16. Regmi R, Poudel S, Regmi RC, Poudel S. Efficacy of commercial insecticide for the management of tomato fruit borer, helicoverpa armigera Hubner, on tomato in chitwan. Nepal. Journal of Agriculture and Forestry university 2018;2:121-132.

17. Safna M, Naik KV, Desai VS, Karmarkar MS, Shinde BD, Raut PP. Evaluation of the efficacy of some insecticides against fruit borer, Helicoverpa armigera
(Hubner) infesting tomato. International Journal of Chemical Studies 2018;6(2):1158-1163.

18. Shah JA, Inayatullah M, Sohail K, Shah SF, Shah S, Iqbal $\mathrm{T}$, et al. Efficacy of botanical extracts and a chemical pesticide against tomato fruit worm, Helicoverpa armigera. Sarhad Journal of Agriculturists 2013;29(1).

19. Shinde ST, Shetgar SS, Badgujar AG. Bio-efficacy of different insecticides against major pest of okra. J. Entomol. Res 2011;35(2):133-137.

20. Sreedhar U. Field evaluation of new insecticides against budworm, Helicoverpa armigera (Hubner) in flue cured Virginia tobacco. Journal of Entomology and Zoology Studies 2019;7(3):417-420.

21. Sridhar Y, Sharma AM. Flubendiamide, a novel insecticide for management of lepidopteron defoliators in soybean. Journal of Legume Research 2014;38(4):551554.

22. Thiruveni T, Karthik P. Evaluation of Flubendiamide 480 SC against fruit borers damage in o kra. International Journal of Chemical Studies 2017;6(1):403-405.

23. Verma S, Ramteke L, Sinha AK, Nandanwar AK, Paikara PR. Effective Management of Gram pod borer Helicoverpa armigera (Hubner) with combination of Neem Seed Kernel Extract (NSKE) and Flubendiamide 39.39 SC in Rainfed areas of Chhattisgarh. International Journal of Applied and Pure Science and Agriculture 2015;1(8):2394-5532. 